\title{
Utilization of Nyctanthes arbor-tristis L. flower and Artocarpus heterophyllus Lam wood extracts as natural dyes for sheepskins leather with different mordants
}

\author{
Dona Rahmawati*, Umi Reza Lestari, Emiliana Kasmudjiastuti \\ Center for Leather, Rubber and Plastics, Ministry of Industry, Jl. Sokonandi No. 9, Yogyakarta 55166, Indonesia \\ *Corresponding author. Tel. +62274512929, Fax. +62274563655 \\ E-mail: dona rahma@kemenperin.go.id
}

Submitted: 23 August 2020

Revised: 22 November 2020

Accepted: 4 December 2020

\begin{abstract}
Natural dye, as dyeing material, delivers beautiful and distinctive color, synthetic chemical free, easy to get, easy to degrade, and produces non-toxic liquid waste. Natural dyes require mordant to attach the dye molecules into the leather fibers. This study aimed to determine the effect of mordant in the leather dyeing process using natural dyes extracted from Artocarpus heterophyllus Lam wood and Nyctanthes arbor-tristis L. flowers. The treatment was using three kinds of mordant, i.e. alum, citric acid, and zinc sulfate, with pre-mordanting method, $3 \%$ by weight of the sheepskins crust leather tanned with chrome and syntan. The result of the dry rub fastness was excellent (score 5). The wet rub fastness of dyed leather with citric acid mordant was good (score $4-4 / 5$ ), while for alum mordant was quite good (score 3/4). Artocarpus heterophyllus Lam wood extract produced better wet rub fastness compared to Nyctanthes arbor-tristis L. flowers extract. Citric acid mordant produced colors with the highest brightness level for both natural dyes extracts compared to alum and zinc sulfate. Artocarpus heterophyllus Lam wood extract produced a brighter color compared to Nyctanthes arbor-tristis L. flowers extract with the same mordant. The visual result of the dyeing process was brownish-yellow.
\end{abstract}

Keywords: Artocarpus heterophyllus Lam, leather dyeing, natural dye, Nyctanthes arbor-tristis L.

\section{INTRODUCTION}

Natural dye is dyeing material obtained from natural resources, such as plants, animals, microbes, and minerals. Natural dyeing agents have long been used for food and have continued to develop into applications for cosmetics, pharmaceuticals, and textiles. With the beginning of synthetic dyes era since the mid-19th century, the use of natural dyes decreased dramatically and practically abandoned by the beginning of the 20th century. Nowadays, global awareness of the environment, ecology, and pollution control leads to an increase in the use of natural dyes in the mid-20th century (Shabbir et al., 2016). Natural dyes are applied to various types of fibers, such as cotton, nylon, hemp, wool, leather, and other materials to provide a distinctive color (Oparah et al., 2014).

Natural dyes are very popular because of the ability to produce a beautiful and distinctive color effect than synthetic dyes. This ability is a very meaningful aesthetic carrying capacity for exclusive products and high artistic value so that they have an appeal to get a specific market segment. Besides, natural dyes are chemical-free, easy to obtain, contain natural components that do not have a pollution load, easily to degrade, and the dyeing process also produces non-toxic liquid waste (Gobalakrishnan et al., 2020). However, with natural dyeing process also has drawbacks, including that it takes a long time so that it requires patience and persistence in the process, and the resulting color tends to be inconsistent.

Unlike fabrics, leather is not a flat material of uniform thickness, but rather a three-dimensional substrate through which dyes can penetrate to different degrees (Oparah et al., 2014). In addition, leather is a substrate consisting of two surfaces with different affinities and accessibility to dyeing agents (Oparah et al., 2014; Dave et al., 2016). Leather dyeing is a transitional process 
between tanning and finishing. Proper leather dyeing increases its value as a commodity and also contributes to its prevalent quality. The mordanting process helps improve the fastness of dye rub (Oparah et al., 2014).

Mordant are metal salts, natural compounds that contain metal ions, or other complex substances used to enhance colorant intake and fixation, as well as fastness properties (İşmal \& Yildirim, 2019). Mordant also plays a significant role in producing dyes that are more wash-resistant and light-resistant. The use of different mordants in the natural dye will produce a different color. Some of generally used metal mordants are alum, ferrous sulphate, zinc sulfate, and stannous chloride. These metal mordants are known for generating wide range of color tones after fixating with natural dyes (Prabhu \& Bhute, 2012). On the other hands, metal mordants are considered harmful to the environment because of the residue in wastewater. To substitute the metal mordants, biomordants are potentially applied as an eco-friendly alternatives. Acetic acid, formic acid, citric acid, tartaric acid, and oxalic acid are some of natural mordants used to replace metal mordants (Inayat et al., 2010; Khalid et al., 2010).

Research on the use of natural dyes for leather with different mordants has been carried out, including filamentous fungi extraction for leather dyeing (Velmurugan et al., 2010), the application of natural dye extract from Bixa orellana seeds for dyeing of leather for shoe upper (Selvi et al., 2013), Curcuma longa (turmeric) extract on chrometanned leather using mordant ferrous sulphate, aluminum sulphate, zinc sulphate, and stannous chloride (Oparah et al., 2014), sheepskin leather dyeing using chestnut shell wastes with mordant potassium aluminum sulphate, copper sulphate, and ferro sulphate (Onem et al., 2016).

Artocarpus heterophyllus Lam. tree belongs to the Moraceae. All parts of the plant emit a thick white sap when injured. Jackfruit is believed to have originated from India, especially the western of Ghats region, and is now widespread in various tropical areas, such as Southeast Asia. Major jackfruit producing countries are China, Vietnam, Myanmar, Thailand, Malaysia, Philippines, Indonesia, Bangladesh, India, Nepal, and Sri Lanka. Jackfruit is also found in Tanzania, Uganda, and Mauritius, as well as throughout Brazil and Jamaica (APAARI, 2012). Artocarpus heterophyllus Lam wood contains flavonoids, one of the natural phenol groups. Flavonoids, saponins, tannins, and anthocyanins belong to woodextractive dyes. Flavonoids are compounds that make the wood colored red, yellow, brown, or blue (Rosyida \& Subiyati, 2018). Tannins are complex organic compounds with amorphous crystals that can dissolve in water to form colored liquids. Color and grade can be affected by the treatment of acids, alkalis, or metal salts. The tannins found in Artocarpus heterophyllus Lam wood are types of morin. This tannin gives Artocarpus heterophyllus Lam its citrus yellow color. The yellow color of morin can be applied to dye textile materials from cotton and silk fabrics with an even and permanent result (Rosyida \& Subiyati, 2018).

Nyctanthes arbor-tristis $L$. is a flowering ornamental plant species native to Southeast and South Asia belonging to the genus nyctanthes. With the distinctive color of the flower crown, the flowers bloom after sunset. The flower crowns are five to eight, white in color with a bright orange center, arranged in groups. The flowers are fragrant and can be used as an orange dye because the stain is very tough to remove. The yellow color from the center of the petals can dye silk and cotton fabrics.

The leather dyeing process using natural dyes is affected by many factors, including the use of mordant. Natural dyes are mostly insubstantial and should be applied to fibers with the help of mordants which have an affinity for both dye and fiber. Mordant adheres to fabric fibers and serves as the point of attachment for dye molecules, has a strong coordination power, and/or is capable of forming weak to medium attractions/interactions, and can thus act as a linking agent to create a natural dye substance when the fiber material is impregnated with mordant (Vankar, 2017). The purpose of this study was to dye the sheep leather using natural dyes extracted from Artocarpus heterophyllus Lam wood and Nyctanthes arbortristis $L$. flowers to determine the effect of mordant on color fastness, as well as the region and color difference.

\section{MATERIALS AND METHODS Materials}

The material used in this study were four and a half sheet of sheepskins crust leathers tanned with chrome and syntan. Natural dyes extracted from Nyctanthes arbor-tristis L. flowers and Artocarpus heterophyllus Lam wood. The 
mordants used as dye fixatives are alum $\left(\mathrm{K}_{2} \mathrm{SO}_{4}\right.$. $\left.\mathrm{Al}_{2}\left(\mathrm{SO}_{4}\right)_{3}\right)$, citric acid $\left(\mathrm{C}_{6} \mathrm{H}_{8} \mathrm{O}_{7}\right)$, and zinc sulfate $\left(\mathrm{ZnSO}_{4}\right)$. Sheepskins leathers were purchased from Piyungan, Yogyakarta; Nyctanthes arbortristis $L$. flowers were bought from the herbal shop in Yogyakarta, Artocarpus heterophyllus Lam wood chips were collected from a carpenter in Bantul, Yogyakarta. Dye fixatives were bought from chemical stores in Yogyakarta; zinc sulfate was obtained from Pedas Jaya store, Denpasar, Bali.

\section{Equipment}

The equipment used in this study were scissors, analytical scale, digital scale, experimental dyeing drums, gas stove (Rinnai), spatula, aluminum pan, electric stove, jerrycans, glassware, crockmeter (AATCC model M238 AA), and Chromameter CR-400.

\section{Methods}

Preparation of natural dye

An amount (200 gram) of each dried Nyctanthes arbor-tristis L. flowers and Artocarpus heterophyllus Lam wood chips were prepared. Aqueous extracts of Nyctanthes arbor-tristis $L$. flowers and Artocarpus heterophyllus Lam wood chips were prepared according to the method by Kasmudjiastuti \& Widhiati (2002). Tap water was used as the solvent for the extraction. The ratio between Nyctanthes arbor-tristis $L$. flowers and Artocarpus heterophyllus Lam wood chips, respectively, with tap water was 1:10 and was boiled until the solution volume remained half, and then filtered with a filter cloth. The boiled solution was labeled as Solution I. After the process was repeated 2 times, Solution II and III were gained.

\section{Leather dyeing process}

Nyctanthes arbor-tristis $L$. flowers and Artocarpus heterophyllus Lam wood extracts were applied to sheepskins leather through tanning

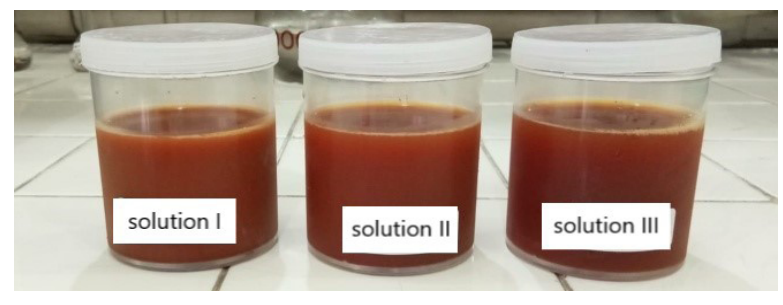

Figure 1. Artocarpus heterophyllus Lam wood extract. process using three different mordants, i.e. alum, citric acid, and zinc sulfate. Each mordant was repeated 3 times, each replicate using a quarter sheet of leather. Each mordant was weighed as much as $3 \%$ of the leather weight and added to solution before the dyeing process.

\section{Material characterization}

In this study, the natural dye extracts were characterized. $\mathrm{pH}$ value of Nyctanthes arbortristis $L$ flowers and Artocarpus heterophyllus Lam wood extracts were measured.

\section{Test for color fastness}

The test for color fastness of dyed sheep leather was conducted according to ISO 20433:2012 Leather - Tests for color fastness (ISO, 2012).

\section{Color difference analysis}

The color difference of leathers dyed with Nyctanthes arbor-tristis $L$ flowers and Artocarpus heterophyllus Lam wood extracts were analyzed using a Chromameter CR-400. Color measurement was prepared according to the Commission Internationale de Eclairage (CIE) color measurement system with 100 standard observer data (Ramalingam \& Jonnalagadda, 2017). The values $L^{*}, a^{*}, b^{*}$ were variables in the CIELAB color space and were described as follows. A more negative $L^{*}$ value indicated darker colors and a more positive $\mathrm{L}^{*}$ value for lighter colors. More negative $\mathrm{a}^{*}$ values implied more green and more positive $a^{*}$ values for more red. More negative values of $b^{*}$ meant more blue and more positive $\mathrm{b}^{*}$ values for more yellow (Dave et al., 2016; Ramalingam \& Jonnalagadda, 2017).

\section{RESULTS AND DISCUSSION}

The sheep leather dyeing process in this study was carried out without the addition of synthetic dyes. The dyeing process was conducted in 3 (three) steps used the most dilute (solution III),

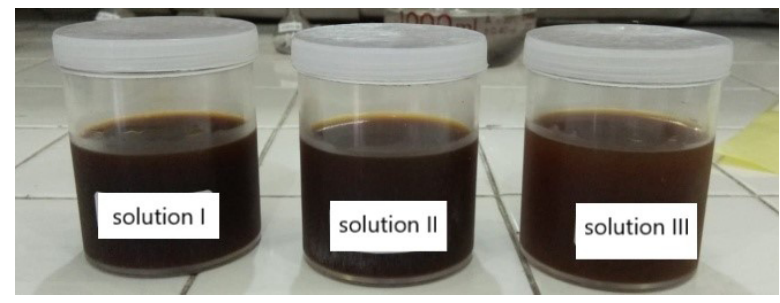

Figure 2. Nyctanthes arbor-tristis $L$ flower extract. 
Table 1. Sheep leather dyeing process.

\begin{tabular}{llcc}
\hline \multicolumn{1}{c}{ Process } & \multicolumn{1}{c}{ Materials } & Amount $(\%)^{*}$ & Time (minute) \\
\hline Wetting back & Water $35^{\circ} \mathrm{C}$ & 200 & \\
& Ammonia & 1 & 60 \\
\multirow{5}{*}{ Mordanting } & 0,5 & \\
& Teepol & 200 & 120 \\
& Water & 3 & Drain \\
Dyeing & (Alum, citric acid, zinc sulfate) & 200 & 30 , drain \\
& Solution III & 200 & 30 , drain \\
& Solution II & 200 & 90, drain \\
Fatliquoring & Solution I & 150 & 30 \\
& Water 40 ${ }^{\circ} \mathrm{C}$ & 6 & 30 \\
& Oil & 6 & 20 \\
& Oil & 0,5 & 15 \\
\hline \multirow{5}{*}{ Aging } & Formic acid & 0,02 & \\
\hline
\end{tabular}

* = by weight of crust sheep leather

solution II, and the most concentrated (solution I), respectively. The dyeing mechanism was processed at $\mathrm{pH} 5$ according to the method in the vegetable tanning process from the wood extract. Dilute solutions are easy to penetrate the leather fibers because they have smaller particles than concentrated solutions (Kasmudjiastuti, 2006).

\section{Material Characterization}

The environtmentally friendly materials used as mordants in this study were alum, zinc sulfate, and citric acid. The characteristics of natural dyes extract solutions used in this study are shown in Table 2.

The $\mathrm{pH}$ measurement results of the Nyctanthes arbor-tristis $L$ flowers and Artocarpus heterophyllus Lam wood extract solutions (solution I, II, III) showed the value of 5. It indicates that the natural dye extracts are classified as acid dyes and have met the $\mathrm{pH}$ requirement for leather dyeing (4.0-7.0).

\section{The Color Fastness}

The results of the dry and wet rub fastness test are presented in Table 3. The leather dyed with Nyctanthes arbor-tristis $L$ flowers and Artocarpus heterophyllus Lam wood extracts using 3 different mordants showed excellent dry rub fastness, and quite good to good in wet rub. The wet rub fastness of dyed leather mordanted with citric acid showed the highest fastness than dyed leather mordanted with alum and zinc sulfate, while the dry rub fastness of dyed leather showed the same results. This was in accordance with Inayat et al (2010), the wet and dry rub fastness of dyed goat crust leather with walnut, eucalyptus, tea, and turmeric dyes post-mordanted with citric acid showed a value of 4-5.

Mordant improves the dye tone by fixing the dyeing agent into leather fiber. In the leather dyeing process, a mordant chemically blends with a soluble dye to make a complex insoluble mixture of high molecular weight pool inside the fiber. The "pool" creates a resistance to the fiber from external effects in the washing and finishing processes. Color fastness depends on the formation of "pools" in the fiber (Khalid et al., 2010). Generally, leathers dyed with Nyctanthes arbor-tristis $L$ flowers extract have lower fastness scores. This can be caused by the afinity of the dye molecules are not binding firmly to the leather fiber so that it can be faded more easily (Kasmudjiastuti, 2006).

Table 2. Natural dyeing materials characteristics.

\begin{tabular}{lllc}
\hline \multicolumn{1}{c}{ Dyeing materials } & \multicolumn{1}{c}{ Major active component } & \multicolumn{1}{c}{ Color } & $\mathrm{pH}$ \\
\hline Nyctanthes arbor-tristis L flower & nyctanthes & yellowish orange & 5 \\
Artocarpus heterophyllus Lam wood & Tannin 'morin' & yellow & 5 \\
\hline
\end{tabular}


Table 3. Color fastness of the leather with different mordant.

\begin{tabular}{clcc}
\hline \multirow{2}{*}{ Natural dye } & \multicolumn{1}{c}{ Mordant } & Wet rub & Dry rub \\
\cline { 3 - 4 } Nyctanthes arbor-tristis L flower & Citric acid & 4 & 5 \\
& Alum & $3 / 4$ & 5 \\
& Zinc sulfate & $3 / 4$ & 5 \\
\multirow{2}{*}{ Artocarpus heterophyllus Lam wood } & Citric acid & $4 / 5$ & 5 \\
& Alum & $3 / 4$ & 5 \\
& Zinc sulfate & 4 & 5 \\
\hline
\end{tabular}

\section{Color Difference Analysis}

The color difference test results show that the appearance of the color on the leather surface to yellow varies depending on the natural dye and mordant used. The results of sample tests with parameters of direction and color difference are presented in Table 4. Testing of the direction and color difference based on brightness (lightness) to color saturation (chroma) and hue (hue). The method used is CIELAB, which is a color space that can include all colors that can be seen by the eye. This color space is a 3-dimensional space in 3 axes, namely L* (brightness), a* (green-red) and $\mathrm{b}^{*}$ (blue-yellow). The reading of the $\mathrm{L}^{*}$ value is 0 $=$ black and $100=$ white, while for the value $\mathrm{a} *+$ $=$ red and $-=$ green. For the value of $b^{*}+=$ yellow and - = blue (Dave et al., 2016)

Table 4 shows the results of color brightness range from 72.46 to 73.56. Nyctanthes arbortristis $L$ flowers extract mordanted with alum gave the darkest color, while Artocarpus heterophyllus Lam wood extract with mordant citric acid gave the brightest shade. Artocarpus heterophyllus Lam wood extract produced lighter color compared to Nyctanthes arbor-tristis $L$ flowers extract with the same mordant. Generally, citric acid gave the palest tone for leather dyed with Artocarpus heterophyllus Lam wood and Nyctanthes arbortristis $L$ flowers extracts, while alum mordant gives the darkest color. The color change occurs from yellow to pale yellow because of the acidic atmosphere (pH 4.5) (Kasmudjiastuti et al., 2001). The results for direction and color difference test in leather dying with Nyctanthes arbor-tristis $L$ flowers and Artocarpus heterophyllus Lam wood extracts using citric acid, alum, and zinc sulfate as mordants show that the higher $a^{*}$ value, the color tends to more red, the higher the $b^{*}$ value, the color has a more yellowish tone. Leather dyed with Artocarpus heterophyllus Lam wood extract exhibit more of reddish color than leather dyed with Nyctanthes arbor-tristis $L$ flowers extract. Leather dyed with Artocarpus heterophyllus Lam wood extract using zinc sulfate mordant shows the most reddish color strength, then citric acid and alum mordants with a* value of 6.19 and 5.68, respectively.

The $b^{*}$ value is the direction from blue to yellow according to the color space in 3 axes. Leather dyed with Artocarpus heterophyllus Lam wood extract gives the highest yellowish color with the mordant of alum, then zinc sulfate, and citric acid with $b^{*}$ value of $39.78,32.52$, and 30.42 , respectively. Leather dyed with Nyctanthes arbor-tristis $L$ flowers extract shows the highest yellowish color using alum mordant with $b^{*}$ value of 30.04, followed by zinc sulfate mordant and citric acid with the same $b^{*}$ value of 28.76 .

The results of this study are in line with Oparah et al (2014) who conducted research on the use of natural dye curcumin for chrome tanned leather, aluminum sulfate mordant resulted in a darker color than using zinc sulfate mordant. The use of Artocarpus heterophyllus Lam wood extract in the leather dyeing process results in higher $\mathrm{a}^{*}$ and $\mathrm{b}^{*}$ values compared to the use of Nyctanthes arbortristis $L$ flowers extract. It shows that Artocarpus heterophyllus Lam wood extract produces a

Table 4. Color difference of the samples.

\begin{tabular}{|c|c|c|c|c|c|c|}
\hline \multirow{2}{*}{ Mordant } & \multicolumn{3}{|c|}{ Artocarpus heterophyllus Lam wood } & \multicolumn{3}{|c|}{ Nyctanthes arbor-tristis $L$ flower } \\
\hline & $\mathrm{L}^{*}$ & $\mathrm{a}^{*}$ & $\mathrm{~b}^{*}$ & $\mathrm{~L}^{*}$ & $\mathrm{a}^{*}$ & $\mathrm{~b}^{*}$ \\
\hline Citric acid & 73.56 & 6.19 & 30.42 & 73.32 & 3.05 & 28.76 \\
\hline Alum & 72.53 & 5.68 & 39.78 & 72.46 & 3.61 & 30.04 \\
\hline Zinc sulfate & 73.09 & 6.92 & 32.52 & 72.94 & 3.80 & 28.76 \\
\hline
\end{tabular}


Table 5. Sheep leather dyed appearance.

\begin{tabular}{|c|c|c|c|}
\hline \multirow{2}{*}{ Natural dyes } & \multicolumn{3}{|c|}{ Mordant } \\
\hline & Alum & Citric acid & Zinc sulfate \\
\hline $\begin{array}{l}\text { Artocarpus } \\
\text { heterophyllus Lam } \\
\text { wood extract }\end{array}$ & & & \\
\hline $\begin{array}{l}\text { Nyctanthes arbor- } \\
\text { tristis } L \text { flowers } \\
\text { extract }\end{array}$ & & & \\
\hline
\end{tabular}

more reddish and yellowish color, or exhibits a more brownish shade on the dyed leather. The visual assessment for dyed leather results in the brownish-yellow color as shown in Table 5. The natural dye's content affected the color direction of the dyed leather. Artocarpus heterophyllus Lam wood extract contains tannins morin with yellow color agent so that it gives a yellowish-brown tone to the leather.

\section{CONCLUSIONS}

Artocarpus heterophyllus Lam wood and Nyctanthes arbor-tristis $L$ flowers can be used as natural dyes for sheep leather and the visual result of the leather dyeing was brownish-yellow. The type of mordant used showed an effect on color fastness to rubbing. Different hues can be obtained on the leather by changing the mordant used. Dyed leather mordanted with citric acid exhibited the highest brightness color compared to alum and zinc sulfate. Artocarpus heterophyllus Lam wood extracts resulted in a brighter shade compared to Nyctanthes arbor-tristis $L$ flowers extract with the same mordant.

\section{ACKNOWLEDGEMENTS}

Authors are grateful to the Head of Center for Leather, Rubber, and Plastics and the research team for the support during this research.

\section{REFERENCES}

APAARI. (2012). Jackfruit improvement in the AsiaPacific region - A status report. Bangkok, Thailand: Asia-Pacific Association of Agricultural Research Institutions.

Dave, H., Ledwani, L., \& Nema, S. K. (2016). Surface modification by atmospheric pressure air plasma treatment to improve dyeing with natural dyes: An environment friendly approach for leather processing. Plasma Chemistry and Plasma Processing, 36, 599-613. https://doi.org/10.1007/ $\underline{\text { s11090-015-9687-9 }}$

Gobalakrishnan, M., Ragavendran, R., Santhosh, E., \& Tamilvanan, R. (2020). A review on the extraction of natural dye from the tree. International Journal of Creative Research Thoughts, 8(4), 1486-1490.

Inayat, A., Khan, S. R., Waheed, A., \& Deeba, F. (2010). Applications of eco friendly natural dyes on leather using different mordants. Proceedings of the Pakistan Academy of Sciences, 47(3), 131135.

İşmal, Ö. E., \& Yildirim, L. (2019). Metal mordants and biomordants. In Shahid-ul-Islam \& B. S. Butola (Eds.), The Impact and Prospects of Green Chemistry for Textile Technology (pp. 57-82). Cambridge, UK: Woodhead Publishing. https:// doi.org/10.1016/B978-0-08-102491-1.00003-4

ISO. (2012). 20433:2012. Leather tests for colour fastness - Colour fastness to crocking. Geneva, Switzerland: International Organization for Standardization.

Kasmudjiastuti, E. (2006). Penggunaan zat warna alam untuk kulit non konvensional. Majalah Kulit, Karet, dan Plastik, 22(1), 20-25. https://doi. org/10.20543/mkkp.v22i1.330

Kasmudjiastuti, E., \& Widhiati, W. (2002). Pengaruh penggunaan bahan pewarna alam dari ekstrak kayu terhadap sifat fisis kulit ikan kakap merah. Majalah Barang Kulit, Karet, dan Plastik, 18(1), 3-9. https://doi.org/10.20543/mkkp.v18i1.265

Kasmudjiastuti, E., Widhiati, W., \& Kuwatno, K. (2001). Penggunaan ekstrak kayu nangka (Artocarpus heterophyllus) sebagai bahan pewarna untuk kulit. Majalah Barang Kulit, Karet, dan Plastik, 17(1), 10-16. https://doi.org/10.20543/mkkp. v17i1-2.252

Khalid, B., Yaqub, A., Arif, M. F., Liaquat, L., \& 
Iqbal, B. (2010). Study of colour measurements of leather dyed with walnut bark natural dye. Pakistan Journal of Scientific and Industrial Research, 53(5), 252-257.

Onem, E., Cin, G., Alankus, A., Pehlivan, H., \& Mutlu, M. M. (2016). Utilization of chesnut shell wastes as a dyeing agent for leather industry. Leather and Footwear Journal, 16(4), 257-264.

Oparah, E. N., Adamu, J. A., \& Giwa, A. (2014). Dyeing potential of Curcuma longa (turmeric) on chrome tanned leather. Nigerian Journal of Scientific Research, 13(2), 67-73.

Prabhu, K., \& Bhute, A. S. (2012). Plant based dyes and mordant: A review. Journal of Natural Products and Plant Resources, 2(6), 649-664.

Ramalingam, S., \& Jonnalagadda, R. R. (2017). Tailoring nanostructured dyes for auxiliary free sustainable leather dyeing application. ACS Sustainable Chemistry and Engineering, 5(6), 5537-5549. https://doi.org/10.1021/acssuschemeng.7b00896

Rosyida, A., \& Subiyati, S. (2018). Pemanfaatan limbah serutan kayu nangka (Artocarpus heterophyllus) untuk pewarnaan kain sutera. Dinamika Kerajinan dan Batik: Majalah Ilmiah, 35(2), 111-118. https://doi.org/10.22322/dkb.v35i2.4301

Selvi, A. T., Aravindhan, R., Madhan, B., \& Rao, J. R. (2013). Studies on the application of natural dye extract from Bixa orellana seeds for dyeing and finishing of leather. Industrial Crops and Products, 43, 84-86. https://doi.org/10.1016/j. indcrop.2012.07.015

Shabbir, M., Rather, L. J., Shahid-ul-Islam, Bukhari, M. N., Shahid, M., Khan, M. A., \& Mohammad, F. (2016). An eco-friendly dyeing of woolen yarn by Terminalia chebula extract with evaluations of kinetic and adsorption characteristics. Journal of Advanced Research, 7(3), 473-482. https://doi. org/10.1016/j.jare.2016.03.006

Vankar, P. S. (2017). Natural dyes for textiles: Sources, chemistry and applications. Cambridge, UK: Woodhead Publishing.

Velmurugan, P., Kamala-Kannan, S., Balachandar, V., Lakshmanaperumalsamy, P., Chae, J., \& Oh, B. (2010). Natural pigment extraction from five filamentous fungi for industrial applications and dyeing of leather. Carbohydrate Polymers, $79(2), \quad 262-268 . \quad$ https://doi.org/10.1016/j. carbpol.2009.07.058 
